\title{
Mother's Parenting Style, Sibling Relationship, and Learning Motivation of Youngest Child Adolescent
}

\author{
Ika Sri Wahyuningsih* \\ Department of Family and Consumer \\ Sciences, \\ Faculty of Human Ecology, \\ Bogor Agricultural University \\ *Corresponding author:
}

\author{
Diah Krisnatuti \\ Department of Family and Consumer \\ Sciences, \\ Faculty of Human Ecology, \\ Bogor Agricultural University \\ ika_s_w@yahoo.com
}

\begin{abstract}
Learning motivation is the the driving force in adolescent to study diligently for reaching the good learning outcomes. This research aimed to analyze the influence of mother's parenting style and sibling relationship to learning motivation of youngest child adolescent. This research was conducted in SMPN X Dramaga Bogor to sample as many as 60 youngest child adolescent ( 30 boys and 30 girls) aged 13-15 years. Authoritative mother's parenting style, warmth, and learning motivation on youngest child adolescent girls better than youngest child adolescent boys. Mother age and birth spacing were negatively correlations with learning motivation of youngest child adolescent while, authoritarian mother's parenting style, authoritative mother's parenting style, warmth and relative power were positively correlations with learning motivation of youngest child adolescent. Learning motivation influenced by mother age, authoritative mother's parenting style, relative power, and conflict.
\end{abstract}

Keywords: adolescent, learning motivation, mother's parenting style, sibling relationship, youngest child

\begin{abstract}
Abstrak
Motivasi belajar menjadi penggerak dalam diri remaja untuk belajar dengan sungguhsungguh guna memperoleh hasil belajar yang baik. Tujuan penelitian ini adalah menganalisis pengaruh gaya pengasuhan ibu dan interaksi saudara kandung terhadap motivasi belajar remaja anak bungsu. Penelitian ini dilakukan di SMPN X Dramaga Bogor dengan sampel penelitian sebanyak 60 orang remaja anak bungsu (30 laki-laki dan 30 perempuan) yang berusia 13-15 tahun. Gaya pengasuhan ibu otoritatif, interaksi kehangatan dan motivasi belajar remaja anak bungsu perempuan lebih tinggi dibandingkan remaja anak bungsu laki-laki. Usia ibu dan rentang usia saudara berhubungan negatif dengan motivasi belajar remaja sedangkan, dimensi gaya pengasuhan ibu otoriter dan otoritatif, dimensi kehangatan dan kekuasaan saudara kandung berhubungan positif dengan motivasi belajar pada remaja anak bungsu. Motivasi belajar dipengaruhi oleh usia ibu, gaya pengasuhan ibu otoritatif, serta dimensi kekuasaan dan konflik.
\end{abstract}

Kata kunci: anak bungsu, gaya pengasuhan ibu, interaksi saudara kandung, motivasi belajar, remaja 


\section{INTRODUCTION}

Adolescence is one of the most important human resources to prepare future generations that will improve the quality of the nation and the country to be more developed and developed. Central Statistic Agency Population Census Results In 2013 the number of adolescents with the proportion of 50.25 percent of boys and 49.75 percent of girls. Hurlock (1980) divides adolescence into two parts, that are early adolescence lasts from 12 to 16 years and late adolescence lasts from the age of 17 to 18 years.

The main features of adolescence include rapid physical growth, high selfawareness, and always interested in trying something new. Adolescence is not the end of the formation of personality but is one of the main stages in the formation of one's personality. The task of adolescent development is to adapt to physical changes, to carry out appropriate gender roles, to recognize itself as part of a generation by acting maturely towards people of his age, and achieving emotional freedom from parents and other adults (Santrock 2003). Youngest children tend to play more are less responsible, less disciplined, more dependent on others, less confident, spoiled, obeying their sister's wishes, and do not want to be governed (Sari 2000).

The parenting style given during the previous development will affect the perception of an adolescences to date (Santrock 2003). A warm and positive relationship between the child and the parents affects the relationship between the child and his brother. Parenting that gived to children is one of the factors influencing sibling interactions (Furman et al. 1997). The need for attention and affection from parents makes a adolescence always wants to win the competition with their brother. Adolescences are very vulnerable to having conflicts in their daily lives, one of which is fighting with siblings. Sibling interaction is said to be a highly influential relationship during an individual's life and lasts longer than a bond with a parent and spouse (Furman et al. 1997). If competition between siblings that occur lowly, it will get high learning motivation (Vevandi 2015).

Motivation is an important thing in the learning process because it can move the individual in directing the action and choose the most useful learning goals for his life (Soemanto 2006). The growth of motivation in a person is based on selfawareness regarding the nature and existence of each life. Meanwhile, extrinsic motivation includes motivation to recognize learning objectives, motivations relating to learning activities and time that owned, and motivation that aims to follow existing rules in the environment (Pelletier et al. 1995). Based on the above description, research on the motivation of learning youngest teens is very important considering the problem of this age group of adolesncence have extrinsic motivation that is more dominant than intrinsic motivation owned in him. Thus it becomes very important to further examine the perceptions of maternal style and sibling interaction on the motivation of adolescent learning as the youngest child.

One of the basic capital of national development is the quality of human resources. The tendency to decrease the motivation of adolescent learning is caused by family factors, parental background, poor parent's attention to children, school environment, class situation, and less controlled adolescents (Purnomo 2012). Amount of 44.30 percent of adolescents have low learning motivation, and overall 
more than three quarters $(85.90 \%)$ of adolescents consider learning as a demand (Novianti 2014). This shows that adolescent self-awareness to achieve the underlying achievement of intrinsic motivation must still be developed in order to achieve sufficient achievement.

Motivation is an important aspect of the learning process. Motivation can also serve as a driver of business and achievement with diligent and diligent effort, and high self-esteem then one will have high learning motivation, both intrinsic and extrinsic motivation to complete the task (Sardiman 2010). Parents who adopt authoritative-style parenting style can improve adolescent learning motivation (Herniati 2011). Family environment can influence the motivation of adolescent learning, the higher the support of family environment, the learning motivation will be higher (Sukirno 2013).

The quality of good parenting style will have an impact on the optimization of learning strategies, as well as increasing the motivation to learn in order to achieve good academic achievement (Hastuti 2009). In addition to parenting style, warmth and power interaction with siblings is also needed to improve the adolescence's learning motivation. Bronfenbrenner (1981) states that learning motivation can be improved through interaction with siblings who have different levels of cognitive ability. The more positive of relationships quality that produced between siblings, the higher the level of adolescent learning motivation (Mirah \& Patricia 2014; Hendriana \& Hendriani 2015). The interaction between adolescents with siblings also plays a role in encouraging, guiding, and directing youngest teens to learn. Parents, especially mothers and siblings, should be able to guide, assist, and direct adolescences in overcoming difficulties that may be faced in learning. It is therefore very important to examine more about maternal care styles, sibling interactions, and motivation to learn as youngest adolescence.

In general, this study aims to analyze the influence of maternal parenting style, sibling interaction, and motivation of learning on youngest teens. The specific objectives of this research are to: (1) identify differences in maternal parenting style, sibling interaction, and adolescent learning motivation on youngest boys and girls, (2) to analyze the relationship of maternal parenting style, sibling interaction, and learning motivation on youngest adolescence, and (3) to analyze the influence of maternal parenting style and sibling interaction on the youngest child's motivation to learn.

\section{METHOD}

This research used cross-sectional study design because the research is done in one section time. This research was conducted at X State Junior High School Dramaga, Bogor District, West Java. Determination of the location is done purposively because it has a large number of students, meet the criteria as respondents. The study included preparation, data collection, data processing, data analysis and report writing.

The population of this study is all students of X State Junior High School Dramaga as youngest child who live at home with siblings and parents. Samples in this study are adolescent boys and girls at stage early adolescence (13-15 years) and the youngest child in his family, have a complete parent and sibling who live in one 
house and raised with the same parents. The reason of choosing youngest adolescence because this period is the time of change of adolescent to find identity and youngest child usually tend to spoiled, less responsible, not burdened by heavy responsibility by parents (Mirah \& Patricia 2014). Researchers assigned 60 students as examples of research with the proportion of 30 adolescences boys and 30 girls. Sampling technique used is purposive sampling (intentionally). The sampling frame can be seen in Figure 1.

The data collected in this study is the primary data. The primary data used in this study are data obtained directly from the sample through self reporting techniques using questionnaires and using categories referring to Ahmed \& Taneepanichskul (2008) that are low $(<60 \%)$, moderate $(60 \%-80 \%)$, and high (> $80 \%$ ) and secondary data used are student data from the school, including: characteristics of adolescents (age and sex), characteristic of siblings (sibling age, sibling age and sex of siblings), family characteristics (mother's age, mother's education, mother's job), and family size.

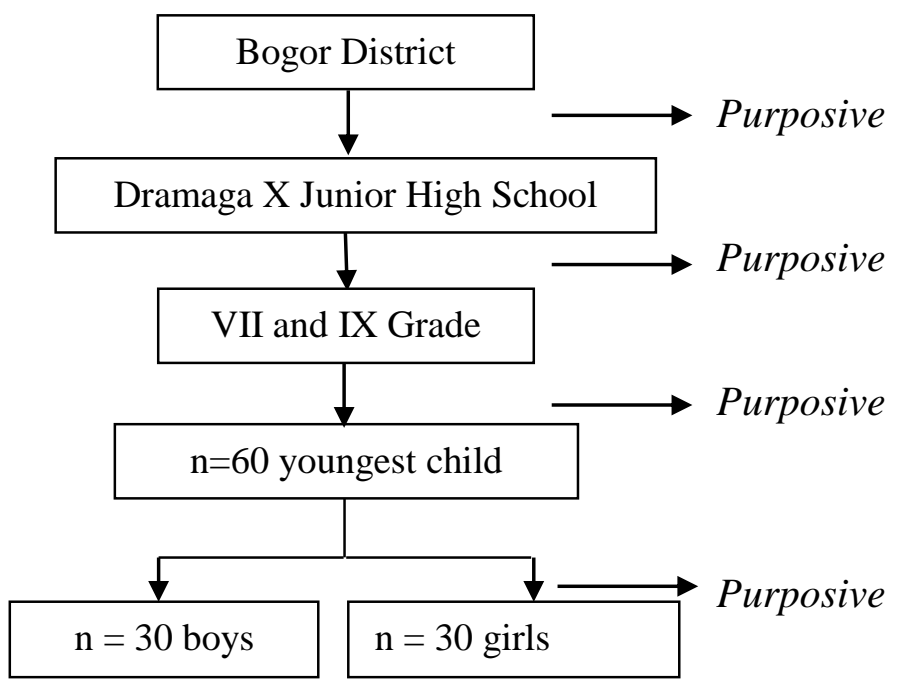

Figure 1 Sampling Frame

Maternal parenting style data was measured using a questionnaire from Buri (1991) that adapted and modified by the researchers and consisting of 24 statement items, 8 questions for authoritarian dimensions, 8 items of authoritative dimension statements, and 8 items of permissive dimension statements. The instrument uses 4 scoring scales ( $1=$ strongly disagree; $2=$ disagree; $3=$ agree; $4=$ strongly agree $)$ with cronbach's alpha maternal care score of 0.631 .

Sibling Relationship Qestionnaire (SRQ) was developed by Jennings (1998) and adapted and modified by researchers consisting of 55 items of statement that is for the warmth dimension of 25 items of statement, dimension of power there are 12 points of the statement, the dimension of conflict there are 12 points statement, and the dimension of competition there are 6 items of question. Assessment of SRQ using Likert scale $1-4$ ( $1=$ not equal, $2=$ rare, $3=$ often; $4=$ very often $)$ with Cronbach's alpha interaction siblings 0.911. The data of learning motivation using questionnaires belong to Pelletier et al. (1995) on the motivation of learning developed by Herniati (2011) and adapted and modified by the researcher consisted 
of 30 items of statement that is for the intrinsic dimension there are 15 items statement and extrinsic dimension 15 points statement. Assessment of learning motivation using Likert scale 1-4 ( 1 = strongly disagree; 2 = disagree; $3=$ agree; 4 $=$ strongly agree) with cronbach's alpha value of 0.871 .

Data analysis was done by using descriptive and inferencing analysis. Data analysis is done in order to give meaning to the results obtained through the type of analysis and testing as follows:

1. Reliability test is used to test the reliability of the measuring instrument.

2. Descriptive analysis is used to explain the characteristics of family, characteristics of adolescent, and characteristics of siblings, maternal parenting style in adolescents, sibling interaction, and motivation to learn in adolescents.

3. Different test (independent sample t-test) is used to see the difference of maternal parenting style, sibling interaction, and motivation to learn based on boys and girls gender category.

4. Relationship test is used to analyze the relationship of family characteristics, sibling characteristics, mothering style, sibling interaction, and learning motivation.

5. Multiple linear regression test is used to analyze the influence of family characteristics, sibling characteristics, mothering style, sibling interaction, and learning motivation.

The multiple linear regression equation used is as follows:

$$
\begin{gathered}
\mathrm{Y} 1=\alpha+\beta_{1} \mathrm{X}_{1}+\beta_{2} \mathrm{X}_{2}+\beta_{3} \mathrm{X}_{3}+\beta_{4} \mathrm{X}_{4}+\beta_{5} \mathrm{X}_{5}+\beta_{6} \mathrm{X}_{6}+\beta_{7} \mathrm{X}_{7}+\beta_{8} \mathrm{X}_{8}+\beta_{9} \mathrm{X}_{9}+\beta_{10} \mathrm{X}_{10} \\
+\beta_{11} \mathrm{X}_{11}+€
\end{gathered}
$$

Information:

$\mathrm{Y}=$ learning motivation

$\mathrm{A}=$ regression constant

$\mathrm{B} 1-\beta 11=$ regression coefficients

$\mathrm{X} 1=$ maternal age (years)

$\mathrm{X} 2=$ mother education (year)

$\mathrm{X} 3$ = family size (persons)

$\mathrm{X} 4$ = age range (year)

$\mathrm{X} 5$ = authoritarian mothering style

$\mathrm{X} 6=$ authoritative mothering style

$\mathrm{X} 7=$ permissive mothering style

$\mathrm{X} 8=$ warmth dimension

$\mathrm{X} 9=$ power dimension

$\mathrm{X} 10=$ dimension of conflict

$\mathrm{X} 11=$ competitive dimension

$€=$ error 


\section{RESULT}

\section{Characteristics of Youngest Young Child's Family}

The results showed that more than two thirds of the youngest boys had elder sisters $(73.30 \%)$ and the rest had older siblings (26.70\%) youngest female adolescents had older siblings $(70.00 \%)$ And the rest have older sisters $(30.00 \%)$. The average youngest teenage boy is 14.03 years old while the youngest female adolescence is 14.13 years old. More than half $(60.00 \%)$ of adolescents have age of adult sibling (> 18 years) while more than one third (40.00\%) adolescent have age of youth (13-18 years old). The average age range of youngest teenage siblings is 5.77 years and youngest female adolescence is 4.87 years. More than three-fourths (78.30\%) of maternal age were in the middle adult category (41-60 years) and the rest $(21.70 \%)$ maternal age was in the young adult category (18-40 years). More than a quarter $(30.00 \%)$ of mothers educated high school graduates and most $(86.70 \%)$ of mothers did not work or as housewives. Nearly half $(46.70 \%)$ of adolescents came from the medium family category (5-6 people) with a large average family of 4.83 people.

\section{Maternity Style}

More than half (53.30\%) adolescent boys and young girls perceive an authoritarian mother-care style in the low category. More than three quarters $(76.70 \%)$ of youngest boys perceive an authoritative maternal care style in the moderate and half $(50.00 \%)$ category of youngest female adolescents perceiving an authoritative mother-caring style in the high category. More than two-thirds $(66.70 \%)$ of youngest teenage boys and most $(80.00 \%)$ youngest female adolescents perceive a permissive mother-care style in the low category.

\section{Interaction Siblings}

Most (83.30\%) adolescent boys and two-thirds (66.70\%) youngest teens have a dimension of warm interaction with siblings in the low category. More than twothirds $(73.30 \%)$ youngest teenage boys and more than half $(66.70 \%)$ youngest female adolescents have a power interaction with siblings in the low category.

All teenage boys $(100.00 \%)$ and most young women $(90.00 \%)$ have conflicting interactions with siblings in the low category. More than half $(60,00 \%)$ of the examples have competitive interaction with siblings in the low category, more than one-third $(33.30 \%)$ examples have interaction of competition with sibling in medium category, and the rest $(6.70 \%)$ example have competition interaction With siblings in high category.

\section{Motivation to learn}

Motivation to learn is an impetus that directs a person to perform an action that is in this direction leads to the act of learning through intrinsic motivation and extrinsic motivation (Santrock 2003). Based on the results of the different test analysis (Table 1) showed a significant difference in intrinsic motivation dimension in female adolescent (79.70) higher than male adolescent (73.33) and also on 
dimension of extrinsic motivation in adolescent girl $(67,78)$ Higher than male adolescents (62.67).

Most young boys $(83.30 \%)$ have moderate learning motivation and more than one-third of youngest girls $(60.00 \%)$ have high learning motivation. Growing motivation to learn in adolescent of woman and man that is parent choose study program that match with competence and interest (Puspitawati 2006).

Table 1 Mean of of index, deviation standard, and difference coefficient of learning motivation in value youngest adolescent by sex

\begin{tabular}{cccc}
\hline Learning Motivation & Boys & Girls & \multirow{2}{*}{ p-value } \\
& Mean \pm DS & Mean \pm DS & - \\
\hline Intrinsic Motivation & $73.33 \pm 10.70$ & $79.70 \pm 12.22$ & $0.036^{*}$ \\
Extrinsic Motivation & $62.67 \pm 8.20$ & $67.78 \pm 9.81$ & $0.033^{*}$ \\
\hline Description: DS = Deviation Standard & & & \\
*significant at $p<0.05 ; * *$ significant at $p<0.01$ & &
\end{tabular}

\section{Maternity Style Relationships and the Interaction of Siblings with Youngest Childhood Motivation Learning}

The results of the correlation test between the variables indicate that there is a negative relationship between maternal age and age range with learning motivation. This shows the younger age of mother and the closer the age range of the siblings will be the higher the motivation to learn that youngest teens have. Other results in this study indicate a positive relationship between authoritarian, authoritative, warmth, and power with learning motivation. This indicates that the higher the authoritarian mother, authoritative, warmth interaction, and power of siblings the higher the juvenile child's learning motivation (Table 2).

Table 2 Correlation coefficient values between characteristics, maternal care styles, brother interactions Biological, with the motivation to learn youngest teens

\begin{tabular}{lr}
\hline Variable & Learning Motivation \\
\hline Age (years) & 0.034 \\
Mother's age (years) & $-0.299^{*}$ \\
Mother's education (years) & -0.131 \\
Family size (persons) & 0.016 \\
Sibling age (years) & -0.243 \\
Age range (years) & $-0.260^{*}$ \\
Authoritarian parenting style & $0.259^{*}$ \\
Authoritative parenting style & $0.473^{* *}$ \\
Permissive parenting style & -0.006 \\
Warmth interaction & $0.513^{* *}$ \\
Power interaction & $0.491^{* *}$ \\
Conflict interaction & 0.058 \\
Rivalry interaction & -0.054 \\
\hline Description $*$ significant at $p<0.05 ; * *$ significant at $p<0.01$
\end{tabular}

Description: * significant at $\mathrm{p}<0.05 ; * *$ significant at $\mathrm{p}<0.01$ 


\section{Influence of Maternal Care Style and Biological Interaction on Youngest Childhood Motivation Learning}

Overall this regression model explain by 35.00 percent influence of research variables on motivation learn youngest adolescence, while the rest equal to 65.00 percent influenced by other variable outside this research. Maternal age negatively affects the motivation of learning youngest teens $(\beta=-0.365)$. This shows that every increase of one unit of mother's age (year), hence will decrease motivation learn equal to 0.365 points. The variable of mother authoritative parenting style has a positive effect on the motivation of learning youngest adolescence $(\beta=0.187)$. This shows that each increase of one authoritative mother-care style unit, it will increase the learning motivation by 0.187 points.

Table 3 Multiple regression test results of characteristic, mothering style, and sibling interaction

\begin{tabular}{lccc}
\hline Variable & $\begin{array}{c}\text { Unstandardized } \\
\text { Coefficient }(\mathrm{B})\end{array}$ & $\begin{array}{c}\text { Standardized } \\
\text { Coefficient }(\beta)\end{array}$ & Sig. \\
\hline Constant & 58.804 & -0.218 & 0.000 \\
Mother's age (years) & -0.365 & -0.068 & $0.093^{*}$ \\
Mother's education (years) & -0.204 & 0.064 & 0.558 \\
Family size (persons) & 0.636 & -0.123 & 0.611 \\
Age range (years) & -0.537 & 0.092 & 0.417 \\
Authoritarian parenting style & 0.074 & 0.230 & $0.077^{*}$ \\
Authoritative parenting style & 0.187 & -0.026 & 0.821 \\
Permissive parenting style & -0.022 & 0.142 & 0.443 \\
Warmth interaction & 0.094 & 0.342 & $0.047 * *$ \\
Power interaction & 0.216 & -0.215 & $0.085^{*}$ \\
Conflict interaction & -0.168 & -0.063 & 0.569 \\
Rivalry interaction & -0.044 & 0.350 \\
\hline Adjusted $R$ Square & \multicolumn{4}{|}{3.887} \\
F & \multicolumn{4}{c}{$0.000^{* * *}$} \\
Sig & Description: * significant at $\mathrm{p}<0.1 ; * *$ significant at $\mathrm{p}<0.05 ; * *$ significant at $\mathrm{p}<0.01$
\end{tabular}

Dimensions of power have a positive effect on the motivation of learning youngest teens $(\beta=0.216)$. This shows that every increase of one unit of sibling interaction will increase the learning motivation by 0.216 points. The dimension of conflict negatively affects the learning motivation of youngest teens $(\beta=-0.168)$. This shows that every increase of one sibling interaction unit will decrease the learning motivation by 0.168 points (Table 3 ).

\section{DISCUSSION}

Overall, most examples have an authoritative mother-style perception of style. meaning children are raised with high control and warmth. Average achievement index of total learning motivation in the medium category and average achievement motivation of adolescent girls is higher (73.74) than male adolescent (68.00). Goleman (1995) also stated that girls tend to have more motivation needs 
to do something in order to maintain and maintain that bond. Mother's age has a negative relationship to the motivation to learn youngest teens. This is in line with Nurrohmaningtyas (2008) which states that the age of younger mothers tend to have good emotional intelligence and will encourage the formation of the youngest child's motivation to learn the good young too. Age range also has a negative relationship with learning motivation of youngest teens. Siblings whose span of only two years or less will have similar skills and skills and have more togetherness of interest so they can share so as to encourage youngest teens to have good learning motivation (Brody 1996).

This study found a positive relationship between mother authoritarian parenting style and learning motivation. This is in line with Lamborn \& Mounts (1991) which states that the authoritarian parenting style will make adolescences have good learning motivation. but low self-esteem. Dehyadegary et al. (2002) states that in an authoritative parenting style. mothers provide compassion and warmth in helping adolescents learn. but at the same time provide boundary rules and have high authority by providing explanations. understandings. desires. goals. and knowledge of parents' principles to adolescents Related to learning motivation. as well as encourage and support adolescents to improve learning motivation. The sibling's interaction on the dimension of warmth and power also has a positive relationship with the juvenile child's learning motivation. This is in line with Herniati (2011) which states that sibling power interactions can increase learning motivation through support received by adolescents.

In this study. maternal age negatively affects adolescent learning motivation. Mother's age tends to be younger have good emotional intelligence and will affect the formation of the youngest child's motivation to learn the youngest is good (Nurrohmaningtyas 2008). The authoritative parenting style has a positive effect on the motivation of adolescent learning. This result is in line with Nurhayati (2013) which concludes that mother's authoritative parenting style influences the way of the child in learning so that the child's awareness in learning will be formed by itself because the parent especially the mother has applied to the child about the responsible attitude as the learner and allows to increase the motivation to learn Adolescences.

The sibling's interaction on the power dimension has a positive influence on the youngest child's teenage motivation. This is in line with Myers (2000) who concluded that the behaviors felt by youngest adolescences by receiving excessive control (coercion) from their older siblings caused adolescences to have good learning motivation. Sibling interaction on the dimension of conflict has a negative effect on the learning motivation of youngest teens. This result is in line with Hendriana and Hendriani (2015) which concludes that if conflicts occur between low relatives it will get high learning motivation.

Each researcher must have a limit in its implementation so that it can be studied further by further research. some of which is the limited number of youngest adolescences in the school. because the location of research is only in one school alone. it would be better if the number of adolescents used more with Ways of involving multiple schools. research still uses adolescent perceptions of maternal care styles and sibling interactions. should involve mothers and siblings to improve data validity. This study also has not seen how the interaction between brothers 
based on your gender. Therefore. for further research is expected to discuss with the involvement of his brother at once in the same time. This study does not include variables of peer relationships that allow to have a large influence on the motivation of learning youngest teens.

\section{CONCLUSION AND SUGGESTION}

\section{Conclusion}

The average youngest teenage boy is 14.03 years old and youngest female youngster is 14.13 years old whereas the average age of younger brother of youngest child is 19.80 years old and age of youngest adolescence is 19.03 years old youngest child. The average age range of siblings with teenage boys is 5.77 years old and the age range of siblings with youngest female teens is 4.87 years. The average age of teenage mother of youngest child is 44.23 years old and 46.47 year old female is in middle adult category (41-60 years old).

Youngest teens perceive an authoritative mother-care style. Total sibling interactions are in the low category. but the sibling warmth interaction is higher than the interaction of power. conflict. and competition. The dimension of warmth interaction is higher among girls than men. The total motivation of studying adolescent girls and men is in the moderate category. but intrinsic and extrinsic motivation of youngest teenage girls is higher than adolescent youngest child.

The younger the mother's age and the closer the teenage age range with her sister is related to the higher motivation of learning that youngest teens have. The higher authoritative and authoritative mother-caregiving styles. and the siblingdimensional interaction of warmth and power relate to the higher learning motivation of youngest teens. Maternal age and conflict interaction have a negative effect on learning motivation. but authoritative mother-care style and power interaction have a positive effect on learning motivation.

\section{Suggestion}

Mother should be able to provide support. guidance. and stimulation to his children to get along with each other through communication. Improving the warmth and motivation interaction that parents can do by minimizing the interaction of power. conflict. and competition between the brothers proportionally through the mother's authoritative parenting style where the nurturing style becomes the proper parenting style done so that the youngest child can become an individual Have a high warmth with his brother and have a better motivation to learn in the future. The interaction of siblings can be enhanced by playing. having fun. and spending a lot of time with relatives. and telling each other things to their relatives. respecting one another. and not just trying to do better in front of their parents.

Parents should also create a favored and comfortable learning place for children and occasionally reward them as attention and appreciation for children to improve their adolescences' motivation by giving hugs. smiles. praising children. saying what parents like and be proud of. Fun. doing activities with children. and playing together. To the school should hold parenting classes and provide socialization to parents related to good parenting style to be applied in real life in 
order to increase the warmth of adolescents with siblings so as to increase the motivation to learn adolescents.

\section{REFERENCE}

[BPS] Badan Pusat Statistika. 2013. Data Statistik Indonesia. Jakarta (ID): Badan Pusat Statistik.

Ahmed. N.. Taneepanichskul. S. (2008). Knowledge. attitude. and practice of dengue fever prevention among the people in male. Maldives. Journal Health Res. 22. 33-37.

Brody. G. H. (1996). Sibling Relationship: Their Causes and Consequences. New Jersey. US: Ablex.

Bronfrenbrenner. U. (1981). The Ecology of Human Development: Experiments by Nature and Design. USA: Library of Congress Cataloging in Publication Data.

Buri. J. R. (1991). Parental authority questionnaire. Journal of Personality Assessment. 57. 110-119.

Dehyadegary. E.. Yaacob. S. N.. Juhari. R. B.. Talib. M. A. 2012. Relationship between parenting style and academic achievement among Iranian adolescents in sirjan. The Institute of Human Development and Family Studies. 8(1). 156-160.

Furman. W.. Buhrmester. D. 1990. Perceptions of sibling relationships during middle childhood and adolescence. J Child Dev. 61. 1387-1398.

. Lanthier. R.. Stocker. C. 1997. Sibling relationships in early adulthood. J Fam Psyc. 11. 210-221.

Goleman. 1995. Kecerdasan Emosi. Jakarta: Gramedia Pustaka Utama.

Hastuti. D. 2009. Pengasuhan: Teori dan Prinsip serta Aplikasinya di Indonesia. Bogor. ID: IPB Press.

Hendriana. A. A.. Hendriani. W. 2015. Hubungan sibling rivalry dengan motivasi berprestasi pada remaja. Jurnal Psikologi Pendidikan dan Perkembangan. 4(1). 46-56.

Herniati. H. 2011. Gaya pengasuhan. konsep diri. motivasi dan prestasi belajar siswa SMA pada berbagai model pembelajaran [Skripsi]. Institut Pertanian Bogor. Bogor

Hurlock. E. 1980. Psikologi Perkembangan. Jakarta. ID: Erlangga.

Jennings. M. 1998. Siblings perceptions of their divorce experiences and qualities of sibling relationship. [Tesis]. Concordia Unviersity. Canada.

Lamborn. S. D.. Mounts. N. S. 1991. Patetterns of competence and adjustment among adolescents from authoritative. authoritarian. indulgent. and neglectful families. J Child Dev. 62. 1049-1065.

Mirah. F. F. E.. Patricia. 2014. Hubungan antara sibling relationship dan motivasi berprestasi pada remaja yang kedua orang tuanya bekerja. J Psyc. 2-23.

Myers. G. D. 2000. Social Psychology. New York. ST: Mcgraw Hill.

Novianti. N. 2014. Pengaruh gaya pengasuhan. motivasi. dan strategi pengaturan diri dalam belajar terhadap prestasi akademik remaja [Skripsi]. Institut Pertanian Bogor. Bogor. 
Nurhayati. D. A. 2013. Pengaruh pola asuh orang tua dan motivasi belajar siswa terhadap prestasi belajar KKPI kelas X program keahlian TKJ dan TAV di SMK PIRI 1 Yogyakarta [Skripsi]. Universitas Negeri Yogyakarta. Yogyakarta.

Nurrohmaningtyas. S. 2008. Pengaruh gaya pengasuhan dan model sekolah terhadap kecerdasan emosional dan motivasi belajar siswa sekolah dasar [skripsi]. Institut Pertanian Bogor. Bogor

Pelletier. L. G.. Tuson. K. M.. Blais. M. R.. Fortier. M. S.. Vallerand. R. J.. Briere. N. M. 1995. Toward a new measure of intrinsic motivation. extrinsic motivation. and amotivation in sports: the sport motivation scale (sms). Journal of Sport and Exercise Psychology. 17. 35-53.

Purnomo. D. 2012. Hubungan antara pemahaman materi. motivasi belajar. dan prestasi belajar pada siswa kelas VIII SMP Taman Dewasa Ibu Pawiyatan Yogyakarta. J Psyc. 1-16.

Sari. M. 2000. Faktor penyebab dan dampak prikologis persaingan antar saudara kandung pada mahasiswa yang tinggal satu kost. Universitas Ahmad Dahlan. [Internet]. [2015 Oktober 08].

Sardiman. A. M. 2004. Interaksi dan Motivasi Belajar Mengajar. Jakarta: PT Raja Grafindo Persada.

Santrock JW. 2003. Adolescence: Perkembangan remaja. Jakarta. ID: Erlangga.

Sukirno. A. 2013. Pengaruh lingkungan keluarga. motivasi belajar. dan minat kompetensi keahlian terhadap prestasi belajar siswa SMK 1 Pundong. Jurnal Pendidikan. 1-10.

Vevandi. T.. Tairas. MMW. 2015. Hubungan sibling rivalry dengan motivasi berprestasi pada remaja. Jurnal Psikologi Pendidikan dan Perkembangan. 4(1). 46-56. 